\title{
KOMUNIKACIJA I ZNANJE RODITELJA O ISKUSTVIMA SVOJE DJECE S PROBLEMIMA U PONAŠANJU - RAZLIKE U PROCJENI RODITELJA I ADOLESCENATA
}

\section{COMMUNICATION AND PARENTAL KNOWLEDGE ABOUT THEIR CHILDREN'S EXPERIENCE WITH BEHAVIORAL PROBLEMS- PARENT-ADOLESCENT DISCREPANCIES}

\author{
Toni Maglica \\ Filozofski fakultet, Sveučilište u Splitu \\ Faculty of Humanities and Social Sciences, University of Split \\ E-mail: tmaglica@ffst.hr
}

\begin{abstract}
SAŽETAK
Roditeljsko znanje, uključenost u djetetove aktivnosti te obiteljska komunikacija drže se jednima od najsnažnijih obiteljskih zaštitnih čimbenika, posebice u adolescenciji kada je pojačano uključivanje u različite probleme u ponašanju. Doživljaji adolescenata i njihove procjene sebe, roditelja i okruženja, nerijetko se razlikuju od roditeljskih. Ovo istraživanje ima za cilj ispitati značajke komunikacije roditelja i adolescenata, roditeljska znanja o iskustvima svoje djece s problemima u ponašanju te utvrditi postoje li razlike u procjenama između roditelja i adolescenata. Istraživanje je provedeno na prigodnom uzorku od $n=447$ adolescenata i $n=447$ njihovih roditelja. Korištenim instrumentarijem ispitivalo se iskustvo adolescenata s problemima u ponašanju, procjena učestalosti komunikacije te razlozi koji obeshrabruju adolescente od razgovora s roditeljima. Iste upitnike popunjavali su adolescenti i njihovi roditelji. Rezultati su pokazali da roditelji podcjenjuju uključenost, odnosno iskustva svoje djece s problemima u ponašanju te, s druge strane, komunikaciju o tim problemima procjenjuju učestalijom nego adolescenti. Razlike u procjeni utvrđene su i kod razloga koji obeshrabruju za razgovor s roditeljima. Adolescenti u najvećoj mjeri kao razlog iskazuju strah od reakcije roditelja koji ih sprečava i obeshrabruje za razgovor s njima. Rezultati govore u prilog postojećim znanjima tog područja te mogu imati praktične implikacije u kreiranju prevencijskih intervencija.

Ključne riječi: adolescenti, roditelji, komunikacija, problemi u ponašanju
\end{abstract}




\section{ABSTRACT}

Parental knowledge and monitoring, involvement in child activities and family communication are perceived as one of the strongest family protective factors, especially in adolescence when young people may have more experience with behavioral problems. Adolescents' perceptions and assessments of themselves, their parents and the environment they grow up in are often different from those of their parents.

This paper aims to analyze characteristics of parent-adolescent communication, parental knowledge about their children's experience with behavioral problems and determine potential discrepancies between parents' and adolescents' perceptions. The research was carried out on a convenient sample of $n=447$ adolescents and $n=447$ parents. By using the appropriate instruments, adolescents' experience with behavioral problems, perception of frequency of communication and reasons discouraging adolescents from talking to their parents were analyzed. Both adolescents and their parents filled in the same questionnaires.

The results have shown that parents underestimate the level of their children's experience with behavioral problems and, on the other hand, overestimate the frequency of communication about these problems compared with adolescents. Discrepancies were also found for reasons discouraging children from talking to their parents. Adolescents mostly attribute this to the fear of parental reaction. The results support existing knowledge in this field and may have strong practical implications for prevention and treatment interventions.

Keywords: adolescents, parents, communication, behavioral problems

\section{UVOD}

Adolescencija je iznimno važno i osjetljivo životno razdoblje praćeno intenzivnim socijalnim, psihološkim i biološkim razvojem. Stoga nije neuobičajeno da na putu odrastanja adolescenti postaju skloni traženju uzbuđenja i eksperimentiranju (Cousijn, Luijten i Feldstein Ewing, 2019). Rezultati istraživanja u Hrvatskoj i u svijetu upućuju na to da, u odnosu na odrasle i djecu, adolescenti u većoj mjeri manifestiraju različite probleme u ponašanju kao što su: konzumacija duhana, alkohola, droga, kockanje, spolno rizična ponašanja i druge internalizirane ili eksternalizirane probleme (WHO, 2018a; ESPAD, 2020; Duell i Steinberg, 2019; Ricijaš, Dodig Hundrić i Huić, 2016; Glavak Tkalić, Miletić i Maričić, 2016; Gohari, Cook, Dubin i Leatherdale, 2020; Wall i sur., 2018) i probleme mentalnog zdravlja (WHO, 2018b, 2014; Polanczyk, Salum, Sugaya, Caye i Rohde, 2015, Currie i sur., 2012). Nije rijetkost da se kod adolescenata istovremeno manifestira veći broj navedenih oblika ponašanja (Kaltenegger, Låftman i Wennber, 2019; Ricijaš, Dodig Hundrić i Kranželić, 2015). Istraživati probleme u ponašanju i probleme mentalnoga zdravlja u

\section{INTRODUCTION}

Adolescence is an extremely important and delicate life period marked by intense social, psychological and biological development. It is only natural that in this stage adolescents tend to seek excitement and experiment new things (Cousijn, Luijten and Feldstein Ewing, 2019). According to results of research, carried out both in Croatia and elsewhere, adolescents, compared with adults and children, are more prone to different behavioral problems, such as tobacco and alcohol consumption, drug abuse, gambling, risky sexual behaviors and other internalizing or externalizing problems (WHO, 2018a; ESPAD, 2020; Duell and Steinberg, 2019; Ricijaš, Dodig Hundrić and Huić, 2016; Glavak Tkalić, Miletić and Maričić, 2016; Gohari, Cook, Dubin and Leatherdale, 2020; Wall et al., 2018), as well as mental health problems (WHO, 2018b, 2014; Polanczyk, Salum, Sugaya, Caye and Rohde, 2015, Currie et al., 2012). Frequently, adolescents may simultaneously display several types of such behaviors (Kaltenegger, Laftman and Wennber, 2019; Ricijaš, Dodig Hundrić and Kranželić, 2015). Given the vulnerability and specific brain development in adolescence 
tom razdoblju iznimno je važno s obzirom na vulnerabilnost i specifično sazrijevanje mozga tijekom adolescencije (Meruelo, Castro, Cota i Tapert, 2017), kao i činjenicu da se većina problema mentalnog zdravlja pojavi prije odraslosti (Campion, Javed, Vaishnav i Marmot, 2020).

Za potrebe ovog rada dalje u tekstu koristit će se pojmom problemi u ponašanju kao krovnim pojmom za kontinuum oblika ponašanja, od onih jednostavnijih, manje težine i opasnosti za sebe i druge, do onih težih posljedica i potrebe za tretmanom (Koller-Trbović, Žižak i Jeđud, 2011). Riječ je o središnjem pojmu koji supsumira ekstremnije oblike tog fenomena na oba smjera, od rizičnih ponašanja preko teškoća pa do poremećaja u ponašanju. Uz takva ponašanja vezane su posljedice i stanja koja treba usmjeravati i mijenjati, a kojima se bave stručnjaci različitih struka i u različitim područjima (Koller-Trbović, Žižak i Jeđud, 2011). Osim toga, budući da su u središtu rada specifične odrednice odnosa roditelja i njihove djece adolescentne dobi, te su se njihovi odgovori međusobno uspoređivali, u radu se u prvome redu koristi terminom „adolescent", ali povremeno, kada se piše u odnosu na roditelja, koristi se i terminom "dijete".

lako su okruženje škole i vršnjaka iznimno važni okolinski čimbenici, obiteljsko okruženje dio je mikrosustava, unutar ekološkog modela razvoja pojedinca (Bronfenbrenner, 1979), u kojem se nalaze najsnažniji rizični i zaštitni čimbenici koje povezujemo s različitim razvojnim ishodima. Sveobuhvatan pregled složenih obiteljskih relacija (odnosa) nadilazi cilj i opseg ovog rada, no rezultati longitudinalnih prospektivnih studija o obiteljskim rizičnim čimbenicima dugi niz godina konzistentno potvrđuju povezanost specifičnih oblika roditeljstva (i roditeljskih ponašanja) s problemima u ponašanju njihove djece. Ta istraživanja najčešće se temelje na teoriji privrženosti (Bowlby, 1958,
(Meruelo, Castro, Cota and Tapert, 2017), as well as the fact that the vast majority of mental health problems emerge before adulthood (Campion, Javed, Vaishnav and Marmot, 2020), it is extremely important to analyze behavioral problems and mental health issues characteristic of this developmental stage.

For purposes of this paper, the term "behavioral problems" shall be used throughout the text as an umbrella term covering a whole spectrum of behaviors, ranging from simple ones that do not bear significant consequences or pose harm for the individual or others, to those that have repercussions and demand treatment (Koller-Trbović, Žižak and Jeđud, 2011). It represents a core term that covers extreme forms of this phenomenon in both directions, from risk behaviors, to behavioral difficulties and behavioral disorders. These types of behaviors imply consequences and conditions that must be directed and changed. Indeed, they have been addressed by experts from different disciplines and areas (Koller-Trbović, Žižak and Jeđud, 2011). Furthermore, since the paper primarily deals with specific key factors of the parent-child relationship, with children being adolescents, and since the answers of the two groups were compared, the term "adolescent" is mostly used. However, the term "child" is occasionally used to refer to the adolescent in relation to his/her parent.

Even though school and peers represent very important environmental settings, family setting is a part of the microsystem within the ecological system of individual development (Bronfenbrenner, 1979) with the largest risk and protective factors that affect different developmental outcomes. A comprehensive overview of complex family relations exceeds the aim and scope of this paper, but the results of prospective longitudinal studies of family risk factors over the years have consistently emphasized 
1969) i teoriji stilova roditeljstva (Baurmind, 1975). Danas, stoga, postoji snažan konsenzus znanstvenika da obiteljska privrženost $i$ kohezija, kvalitetni obiteljski odnosi, zadovoljstvo unutar obitelji i kvalitetna komunikacija predstavljaju obiteljske zaštitne čimbenike koji štite mentalno zdravlje, doprinose osjećaju dobrobiti pojedinca i preveniraju probleme u ponašanju kod djece (Alm, Laftam, Sivertsson i Bohman, 2020; Reed i sur., 2015; Luthar i Zelazo, 2003, Masten, 2001, prema Velez, Braver, Cookston, Fabricius i Parke, 2020). Osim navedenoga, kada su u pitanju adolescenti, odnos roditelja i djeteta temeljen na znanju roditelja o aktivnostima svojega djeteta i njihovoj kvalitetnoj komunikaciji, drži se ključnim elementom roditeljstva koji predstavlja zaštitni čimbenik za razvoj mlade osobe (Keijsers i sur. 2010; Kapetanovic i Boson, 2020).

Znanje roditelja o aktivnostima adolescenata odnosi se na zainteresiranost i uključenost roditelja, poznavanje njegovih navika, prijatelja te uključuje roditeljski nadzor nad ponašanjem djeteta. Takvi roditeljski postupci predstavljaju snažne obiteljske zaštitne čimbenike, posebice kad je riječ o problemima u ponašanju vezanima uz ovisnosti (Canale i sur., 2016; Farrington, Loeber i Ttofi, 2011; Mihić, Musić i Bašić, 2013). $S$ druge strane, nizak nadzor s roditeljske strane jedan je od najsnažnijih prediktora problema u ponašanju (Farrington, Loeber i Ttofi, 2011). Važno je razlikovati nadzor nad ponašanjem u odnosu na psihološki nadzor, odnosno kontrolu jer, dok se nadzor nad djetetovim ponašanjem povezuje s niskom razinom eksternaliziranih problema u ponašanju, visoka razina psihološkog nadzora, u kojem se koristi i krivnjom, može dovesti do internaliziranih i eksternaliziranih problema u ponašanju (De Kemp, Scholte, Overbeek i Engels, 2006). Tek kada roditelji imaju saznanja o svakodnevnim aktivnostima svoje djece, otvara im se mogućnost adekvatna odgovora na njihove potrebe radi zaštite od štetnih utjecaja i poticanja njihova the link between specific parenting styles (and parental behaviors) and behavioral problems of their children. This research is most often based on the attachment theory (Bowlby, 1958, 1969) and parenting styles theory (Baurmind, 1975). Researchers thus strongly agree that family attachment and cohesion, high-quality family relations, satisfaction within family and good communication all form protective family factors that protect mental health, promote individual wellbeing and prevent behavioral problems in children (Alm, Laftam, Sivertsson and Bohman, 2020; Reed et al., 2015; Lutahr and Zelazo, 2003, Masten, 2001, as cited in Velez, Braver, Cookston, Fabricius and Park, 2019). In addition to that, in respect of adolescents, the parent-child relationship based on parents' awareness of their children's activities and good communication represent key parenting elements that form protective factors for young person's development (Keijsers et al., 2010; Kapetanovic and Bosnon, 2020).

Parents' awareness of adolescents' activities includes interest and engagement on the part of the parent, knowledge about child habits, his/her friends and monitoring of the child behavior. These parental practices are strong family protective factors, in particular in case of addition-related behavioral problems (Canale et al., 2016; Farrington, Loeber and Ttofi, 2011; Mihić, Musić and Bašić, 2013). On the other hand, low parental monitoring is one of the strongest predictors of behavioral problems (Farrington, Loeber and Ttofi, 2011). It is very important to distinguish between parental monitoring of child behavior and psychological monitoring / psychological control because, while parental monitoring is linked to low level of externalizing behavioral problems, pronounced psychological control that may rely on guilt induction can result in both internalizing and externalizing behavioral problems (DeKemp, Scholte, Overbeek and Engels, 2006). Only if 
pozitivna razvoja (Kapetanovic, Bohlin, Skoog i Gerdner, 2017).

Komunikacija roditelja i djece ključna je za ostvarivanje i osnaživanje povezanosti i intimnosti, te pridonosi emocionalnoj kvaliteti odnosa roditelj - dijete (Ying i sur., 2015). Kada su u pitanju adolescenti, literatura najčešće navodi važnost komunikacije koju iniciraju roditelji i dobrovoljnu komunikaciju adolescenata. Roditeljsko iniciranje komunikacije s adolescentom, traženje informacija od svoje djece, postavljanje pitanja (koja su često povezana i s nadzorom i postavljanjem pravila), omogućuju roditeljima znanja i informacije o svojoj djeci, pokazuju uključenost, zainteresiranost, te omogućuju podršku djetetu kada je ona potrebna (Fletcher, Steinberg i Williams-Wheeler, 2004; Pinquart, 2017). S druge strane, Stattin i Kerr (2000) isticali su dobrovoljno komuniciranje s roditeljima koje iniciraju sami adolescenti. Kad se adolescenti osjećaju emocionalno povezani i bliski s roditeljima, raste vjerojatnost da će se povjeriti svojim roditeljima i podijeliti s njima određene informacije (Tilton-Weaver i sur., 2010), što se drži jednim od najsnažnijih zaštitnih čimbenika za mentalno zdravlje adolescenata, primjerice depresivnost (Hamza i Willoughby, 2011), ali i eksternalizirane simptome (Kapetanovic i sur., 2020). Pritom treba imati na umu da roditeljska nastojanja u tome da imaju saznanja o svojoj djeci ne bi smjela biti intruzivna jer ih adolescenti tada doživljavaju pretjerano kontrolirajućim i ugrožavajućim za svoje emocije i privatnost (Hawk, Hale, Raaijmakers i Meeus, 2008), što onda može negativno utjecati na razvojne ishode u djece (Hessel, He i Dworkin, 2017).

Doživljaji adolescenata i njihove procjene sebe, svojih roditelja i okruženja u kojem odrastaju, nerijetko se razlikuju od roditeljskih. Kada je u pitanju procjena roditeljskih ponašanja, roditelji obično percipiraju vlastita roditeljska ponašanja u boljem svjetlu nego što to procje- parents are aware of their children's day-today activities, they can adequately respond to their needs in order to protect them from negative influence and promote their positive development (Kapetanovic, Bohlin, Skoog and Gerdner, 2017).

Parent-child communication is crucial for building and strengthening connectedness and intimacy and contributes to affective qualities of parent-child relationships (Ying et al., 2015). In respect of adolescents, the literature mostly emphasizes the importance of communication initiated by parents and voluntary communication on the part of adolescents. Parent-initiated communication, solicitation, asking questions (that are often connected to monitoring and rules setting) allow parents to acquire knowledge and information about their children, demonstrate engagement, interest and provide support when needed (Fletcher, Steinberg and Williams-Wheeler, 2004; Pinquart, 2017). On the other hand, Stattin and Kerr (2000) pointed to adolescent-driven voluntary communication. If adolescents feel attached and connected to their parents, they are more likely to turn to them and disclose certain information (Tilton-Weaver et al., 2010) and this seems to be the strongest protective predictor of adolescent mental health, including depressive symptoms (Hamza and Willoughby 2011), but also externalizing problems (Kapetanovic et al. 2020). Sometimes, however, parental practices to have certain insights about their children should not be intrusive because they can be perceived by adolescents as overly controlling and threatening in terms of their emotions and privacy (Hawk, Hale, Raaijmakers i Meeus, 2008), which, in its turn, may have a negative impact on children's developmental outcomes (Hessel, He and Dworkin, 2017).

Adolescents' perceptions and assessments of themselves, their parents and the environment 
njuju njihova djeca (Maglica, 2017; Hou i sur., 2019; Janssens i sur., 2015, prema Kapetanovic i Boson, 2020). Ferić Šlehan i Kranželić (2008) navode da su najveće razlike u percepciji adolescenata i roditelja kada je riječ o obiteljskom okruženju, u procjeni dogovaranja i komunikacije u obitelji. Rezultati njihovog istraživanja, baš kao i kod Maglice (2017), upućuju na zaključak da adolescenti percipiraju prisutnost komunikacije u obitelji nižom nego što to procjenjuju njihovi roditelji. Takve razlike u procjenama u nekim su istraživanjima povezane s rizičnim ponašanjima adolescenata i slabijim mentalnim zdravljem (De Los Reyes i Kazdin, 2005; Guion, Mrug i Windle, 2009; Reynolds, MacPherson, Matusiewicz, Schreiber i Lejuez, 2011). Primjerice, razlike u procjeni roditeljskih ponašanja, kada su u pitanju kontrola i discipliniranje, mogu biti prediktori veće incidencije internaliziranih problema (Maurizi, Gershoff i Aber, 2012), eksternaliziranih problema (Gaylord, Kitzman i Coleman, 2003) i lošije dobrobiti djeteta (Kapetanovic i Boson, 2020).

U skladu s navedenim spoznajama, cilj je ovoga rada ispitati značajke komunikacije roditelja i adolescenata, roditeljska znanja o iskustvima svoje djece s problemima u ponašanju te utvrditi postoje li razlike u procjenama između roditelja i adolescenata.

Da bi se ostvario navedeni cilj, postavljeni su sljedeći istraživački problemi i pripadajuće hipoteze:

1. Ispitati roditeljsko znanje o uključenosti i iskustvima njihove djece s problemima u ponašanju te ga usporediti sa samoiskazom adolescenata.

Hipoteza 1 od koje se polazi je da postoje razlike u procjeni roditelja i adolescenata o iskustvima s problemima u ponašanju na način da adolescenti u većoj mjeri izvještavaju o takvim iskustvima. they grow up in are often different from those of their parents. In terms of parenting, parents usually perceived their own parenting more positively than their children (Maglica, 2017; Hou et al., 2019; Janssens et al., 2015, as cited in Kapetanovic and Boson, 2020). Ferić Šlehan (2008) states that the most pronounced parent-adolescent discrepancies in respect of family environment lie in perceptions of negotiations and family communication. Her research results, as well as those found in research conducted by Maglica (2017) indicate that adolescents perceive their family communication poorer than their parents. Some research link these discrepancies to risk behaviors and poorer mental health among adolescents (DeReyes and Kazdin, 2005; Guion et al.., 2009; Reynolds et al., 2011). For example, parent-adolescent discrepancies in terms of control and discipline may be predictive of higher incidence of internalizing (Maurizi et al., 2012), as well as externalizing problems (Gaylord et al., 2003) and poorer well-being of the child (Stuart and Jose, 2012; Kapetanovic and Boson, 2020).

In line with these findings, this paper aims to analyze characteristics of parent-adolescent communication, parental knowledge about their children's experiences with behavioral problems and determine potential parent-adolescent discrepancies in terms of perceptions.

In order to achieve this aim, the paper addresses the following research problems and accompanying hypotheses:

1. Analyze parental knowledge about their children's experiences with behavioral problems and compare it with adolescent self-reports.

The Hypothesis 1, representing the starting point, claims that there are discrepancies in parents' and adolescents' perceptions of behavioral problems whereby adolescents 
2. Utvrditi razlike u procjeni roditelja i adolescenata o učestalosti komunikacije o problemima u ponašanju.

Hipoteza 2 za ovaj istraživački problem je da postoji razlika u procjeni učestalosti komunikacije o problemima u ponašanju na način da roditelji procjenjuju svoju komunikaciju učestalijom u odnosu na adolescente.

3. Ispitati koji razlozi obeshrabruju adolescente za razgovor s roditeljima o temama vezanim uz probleme u ponašanju te postoji li razlika u procjeni tih razloga među roditeljima i adolescentima.

Hipoteza 3 postavljena je na način da se očekuju razlike roditelja i adolescenata o razlozima koji obeshrabruju adolescente od komunikacije sa svojim roditeljima o temama vezanim uz probleme u ponašanju.

\section{METODOLOGIJA ISTRAŽIVANJA}

\section{Uzorak}

Istraživanje je provedeno na prigodnom uzorku od $\mathrm{N}=477$ adolescenata $\mathrm{u}$ dobi od 14 do 19 godina (Mdob $=15$, SDdob $=1,17)$ i $\mathrm{n}=$ 477 njihovih roditelja u dobi od 30 do 63 godine $(\mathrm{Mdob}=45, \mathrm{SDdob}=5,50)$. Uzorak je formiran u srednjim školama Splita i Zagreba pri čemu se vodilo računa da budu zastupljene trogodišnje i četverogodišnje strukovne škole te gimnazije. U odnosu na grad u kojem žive, od ukupno $n=$ 894 sudionika, $\mathrm{n}=410$ roditelja i adolescenata je iz Zagreba (45,9\%), dok je njih $n=484$ iz Splita (54,1\%). U subuzorku roditelja $\mathrm{n}=191$ su očevi (42,7\%), a $n=256$ majke (57,3\%), a u subuzorku adolescenata $\mathrm{n}=203$ su djevojke $(45,4 \%)$, a $n=244$ su mladići $(45,9 \%)$. report on them more frequently than their parents.

2. Establish discrepancies in parents' and adolescents' reports on parent-adolescent communication about behavioral problems.

The related Hypothesis 2 indicates a discrepancy in perception of frequency of communication about behavioral problems whereby parents overestimate the level of parent-adolescent communication compared with adolescents.

3. Analyze the reasons that discourage adolescents from talking to their parents about topics related to behavioral problems and establish potential discrepancies in parents' and adolescents' perception of those reasons.

The Hypothesis 3 is formulated so as to anticipate discrepancies in parents' and adolescents' reports on reasons discouraging adolescents from communicating with their parents about topics related to behavioral problems.

\section{RESEARCH METHODOLOGY}

\section{Sample}

The research was carried out as a survey on a convenient sample of $\mathrm{N}=477$ adolescents aged 14-19 $($ Mage $=15$, SDage $=1,17)$ and $n=477$ parents aged 30-63 (Mage $=45$, SDage $=5,50$ ). Participants were recruited from secondary schools in Split and Zagreb. Vocational schools with three-year and four-year programs were represented, plus grammar schools. In terms of place of residence, of $n=894$ participants, $n=410$ parents and adolescents came from Zagreb (45.9\%) and $n=484$ from Split (54.1\%). Within the subsample of parents, fathers accounted 


\section{Instrumentarij}

$\mathrm{U}$ istraživanju je korišten Upitnik (samo) procjene iskustva adolescenata s problemima u ponašanju i Upitnik (samo)procjene komunikacije o problemima u ponašanju. S obzirom na cilj istraživanja, oba upitnika popunjavali su adolescenti i njihovi roditelji. Navedeni upitnici predstavljaju modificiranu verziju anketnog upitnika koji su razvili prof. Jeffrey Derevensky i suradnici sa Sveučilišta McGill u Montrealu, a tim hrvatskih znanstvenika adaptirao za potrebe znanstvenoistraživačkog projekta "Kockanje mladih u Hrvatskoj".

Upitnik (samo)procjene iskustva adolescenata s problemima u ponašanju sastoji se od 14 tvrdnja, odnosno liste različitih problema u ponašanju specifičnih za razdoblje adolescencije (npr. konzumiranje alkohola, droga, nezaštićeni seksualni odnosi, kockanje/klađenje, depresivnost i dr.). Već je ranije navedeno, popunjavali su ga adolescenti (samoiskazi) i roditelji (procjena za adolescenta koji je sudjelovao u istraživanju) pri čemu su sudionici birali odgovor "ne" ili "da" koji se odnosi na uključenost, odnosno iskustvo s navedenim problemom u ponašanju.

Upitnikom (samo)procjene komunikacije o problemima u ponašanju ispitivala se učestalost komunikacije roditelja i adolescenata o problemima u ponašanju. Riječ je o 14 istovjetnih problema u ponašanju za koje su sudionici ranije popunjavali imaju li ili nemaju iskustva s njima. Taj su upitnik također popunjavali adolescenti i njihovi roditelji, a ponuđeni odgovori kretali su se na ljestvici od četiri stupnja: nikada, rijetko, ponekad, često i redovito. Osim toga, u tom upitniku sudionici su iskazivali slaganje (od 1 - uopće se ne slažem do 5 - u potpunosti se slažem) s tvrdnjama koje se odnose na razloge koji obeshrabruju ili ograničavaju adolescente od razgovora sa svojim roditeljima. Neke od ponuđenih tvrdnja su sljedeće: „strah od kažnjavanja“, , strah od razočaranja“" , "misli da ga/ for $n=191$ (42.7\%), mothers for $n=256$ (57.3\%). Within the subsample of adolescents, $n=203$ were girls (45.4\%) and $n=244$ were boys (45.9\%).

\section{Instruments}

Self-report Questionnaire on Behavioral Problems for Adolescents and Self-report Questionnaire on Communication about Behavioral Problems were used in the research. Given the research aim, adolescents and their parents filled in both questionnaires. The questionnaires are modified version of the questionnaire developed by Professor Jeffrey Derevensky and his associates from the McGill University, Montreal, and adapted by a team of Croatian researchers for their project titled "Youth Gambling in Croatia".

The Self-report Questionnaire on Behavioral Problems for Adolescents includes 14 statements listing different behavioral problems in adolescence (e.g. alcohol consumption, drug abuse, unprotected sex, gambling, depression etc.). As previously explained, the questionnaire was filled in by adolescents (self-report) and their parents (report regarding the adolescent participant). Yes/no questions regarding adolescents' experience with the listed behavioral problems were used.

The Self-report Questionnaire on Communication about Behavioral Problems was used to analyze the frequency of parent-adolescent communication about behavioral problems. The questionnaire covers the same 14 problems previously addressed by the participants in terms of whether they had experienced them. This questionnaire was also filled in by both adolescents and their parents. A four-point scale was used with options: never, rarely, sometimes, often and regularly. In addition, the participants had to specify their level of agreement (whereby 1 - strongly disagree and 5 - strongly 
je neće razumjeti“, "roditelj ne zna dovoljno o takvim temama".

\section{Postupak provedbe istraživanja}

Istraživanje je dio šireg znanstvenoistraživačkog projekta za koji je dobivena suglasnost Ministarstva znanosti, obrazovanja i sporta te Etičkog povjerenstva Edukacijsko-rehabilitacijskog fakulteta Sveučilišta u Zagrebu. Istraživanje je provedeno 2016. godine respektirajući sve odrednice Etičkog kodeksa istraživanja s djecom (Ajduković i Kolesarić, 2003). Adolescenti su upitnik popunjavali u učionici, tijekom školskog sata, dok su njihovi roditelji bili pozvani u školu radi sudjelovanja u istraživanju. Ispunjavanje upitnika trajalo je 45 minuta, a provedeno je prema načelu papir-olovka. Sudionici su detalje o samom istraživanju dobili usmenim i pisanim putem. Upoznalo in se da će podatci istraživanja biti valjani samo ako su upitnik popunili i roditelj $i$ adolescent, te da su stoga upitnici šifrirani. Šifre su kreirali sami sudionici, a način i ključ formiranja šifre posebno je objašnjen uz detaljnu pisanu uputu. Ključ za kreiranje šifre koncipiran je na način da apsolutno sačuva identitet sudionika, čime je osigurana anonimnost. Sudjelovanje u istraživanju bilo je dobrovoljno te su sudionici u svakom trenutku mogli odustati bez ikakvih posljedica.

\section{Rezultati i rasprava}

Prvi istraživački problem odnosio se na ispitivanje roditeljskog znanja o iskustvima svoje djece s problemima u ponašanju te usporedba sa samoiskazom adolescenata. Za potrebe tog istraživačkog problema provedena je deskriptivna statistika kao i Hi-kvadrat test, a rezultati su prikazani u Tablici 1.

Kako je razvidno iz Tablice 1. utvrđene su razlike u procjeni roditelja i adolescenata za gotovo sve probleme u ponašanju, i to na agree) with statements regarding the reasons discouraging or restraining adolescents from talking to their parents. Some of the listed statements were: "fear of punishment", "fear of disappointment", "thinks that he/she will not understand him/her", "parent does not have sufficient knowledge about those topics".

\section{Procedure}

The research survey forms a part of a wider research approved by the Ministry of Science, Education and Sport and the Ethics Committee of the Faculty of Education and Rehabilitation Sciences at the University of Zagreb. The survey was carried out in 2016, in line with rules of the Ethical Code for Research with Children (Ajduković and Kolesarić, 2003). Adolescents filled in the questionnaire in the classroom, during lessons. Their parents were invited to school to take part in the survey. It took 45 minutes to complete the questionnaire. The pen-andpaper method was used. Both written and verbal information was provided to the participants to inform them about the survey. They were told that the survey information would be valid only if provided by both parents and adolescents so the questionnaires were coded. The codes were created by the participants themselves. They were given a detailed information sheet explaining the rules on how to create a code. Codes were created in a way to keep the subjects' identity confidential to a maximum degree and this ensured the anonymity of the research process. The participation was voluntary and participants could withdraw at any point without any consequences.

\section{Findings and Discussion}

The first research problem focused on analyzing parental knowledge about their children's experiences with behavioral problems and compare them with adolescent self-reports. 


\section{Tablica 1. Samoiskaz adolescenata i procjena roditelja o uključenosti/iskustvima adolescenata s problemima u ponašanju}

Table 1. Adolescent Self-reports and Parental Perception of Adolescent Experiences with Behavioral Problems

\begin{tabular}{|c|c|c|c|c|}
\hline $\begin{array}{l}\text { Problemi u ponašanju: } \\
\text { Behavioral problems: }\end{array}$ & $\begin{array}{c}\text { Adolescenti } \\
\text { Adolescents } \\
\%\end{array}$ & $\begin{array}{c}\text { Roditelji } \\
\text { Parents } \\
\%\end{array}$ & $x^{2}$ & $\mathbf{p}$ \\
\hline $\begin{array}{l}\text { Vršnjačko nasilje u školi } \\
\text { School bullying }\end{array}$ & 33,4 & 26,1 & 5,643 & $<, 050$ \\
\hline $\begin{array}{l}\text { Konzumiranje alkohola } \\
\text { Alcohol consumption }\end{array}$ & 57,9 & 19,9 & 135,614 & $<, 001$ \\
\hline $\begin{array}{l}\text { Konzumiranje droga } \\
\text { Drug abuse }\end{array}$ & 12,1 & 2,3 & 32,381 & $<, 001$ \\
\hline $\begin{array}{l}\text { Nezaštićeni seksualni odnosi / maloljetničke trudnoće } \\
\text { Unprotected sex/teenage pregnancies }\end{array}$ & 7,4 & 1,8 & 15,863 & $<, 001$ \\
\hline $\begin{array}{l}\text { Pretilost / poremećaji hranjenja } \\
\text { Obesity/eating disorders }\end{array}$ & 19,0 & 12,8 & 6,572 & $<, 050$ \\
\hline $\begin{array}{l}\text { Kockanje/klađenje } \\
\text { Gambling/betting }\end{array}$ & 30,9 & 9,8 & 61,504 & $<, 001$ \\
\hline $\begin{array}{l}\text { Vožnja pod utjecajem alkohola } \\
\text { Driving under the influence (DUI) }\end{array}$ & 6,3 & 1,1 & 18,298 & $<, 001$ \\
\hline $\begin{array}{l}\text { Pušenje } \\
\text { Smoking }\end{array}$ & 44,5 & 23,5 & 44,509 & $<, 001$ \\
\hline $\begin{array}{l}\text { Provođenje previše vremena na internetu (Facebook, chat, društvene mreže i dr.) } \\
\text { Spending too much time online (Facebook, chat, social networks etc.) }\end{array}$ & 71,1 & 70,2 & ,260 & $>, 050$ \\
\hline $\begin{array}{l}\text { Izloženost opasnostima i rizicima interneta } \\
\text { Exposure to cyber risks and threats }\end{array}$ & 24,4 & 41,8 & 31,376 & $<, 001$ \\
\hline $\begin{array}{l}\text { Depresivnost } \\
\text { Depressive episodes }\end{array}$ & 35,3 & 11,2 & 73,552 & $<, 001$ \\
\hline $\begin{array}{l}\text { Negativna slika o vlastitom tijelu } \\
\text { Negative body image }\end{array}$ & 39,8 & 20,8 & 38,790 & $<, 001$ \\
\hline $\begin{array}{l}\text { Pretjerano igranje videoigara } \\
\text { Heavy video gaming }\end{array}$ & 36,7 & 39,6 & 2,904 & $>, 050$ \\
\hline $\begin{array}{l}\text { Spolno prenosive bolesti } \\
\text { Sexually transmitted diseases (STDs) }\end{array}$ & 1,1 & 0,4 & 2,287 & $>, 050$ \\
\hline
\end{tabular}

Legenda/Legend: $\chi^{2}-\mathrm{Hi}$-kvadrat test/Chi-square test

način da adolescenti u većoj mjeri samoiskazuju o iskustvima s problemima u ponašanju, nego što to za njih procjenjuju njihovi roditelji. Razlike nisu utvrđene samo za probleme u ponašanju, koji se odnose na provođenje previše vremena na internetu i videoigrama, kao i za spolno prenosive bolesti. Promatrajući postotke, adolescenti $(71,1 \%)$ baš kao i njihovi roditelji $(70,2 \%)$ u najvećoj mjeri suglasno iskazuju da provode previše vremena na internetu (Facebooku, različitim chat-ovima i drugim društvenim mrežama). Navedeno ne iznenađuje s obzirom na to da je riječ o ponašanjima koja su lako vidljiva, manifestiraju se u obiteljskom domu, ne percipiraju se osobito rizičnima te ih adolescenti ni ne kriju od roditelja. Najniže
To tackle the problem, descriptive statistical analysis and the chi-square test were used. The Table 1 shows the obtained results.

As the Table 1 shows, discrepancies in parents' and adolescents' reports were found for almost all of the listed behavioral problems, whereby adolescents report on them more frequently than their parents. No discrepancies were found for spending too much time online, video gaming and STDs. In percentage terms, adolescents $(71.1 \%)$, as well as their parents $(70.2 \%)$, mostly agree that they spend too much time online (on Facebook, various chat apps and other social networks). These findings were expected because the listed behaviors 
frekvencije, kod adolescenata i roditelja, odnose se na probleme u ponašanju vezane uz nezaštićene seksualne odnose, maloljetničke trudnoće i spolno prenosive bolesti (iako su kod potonje navedenih utvrđene značajne razlike u procjeni među djecom i roditeljima). Uočavaju se i relativno visoke frekvencije uključenosti adolescenata u konzumiranje alkohola (57,9\%), pušenja (44,5\%), ali i internaliziranih problema mentalnoga zdravlja kao što su depresija (35,3\%) i negativna slika o vlastitom tijelu (39,8\%). S druge strane, svega $11,2 \%$ roditelja misli da su im djeca imala iskustva s osjećajima depresije. Velike razlike u procjenama roditelja i adolescenata razvidne su upravo kod osjećaja depresivnosti, ali i kod ponašanja vezanih uz ovisnosti - konzumiranje alkohola i kockanje/ klađenje.

Navedeni rezultati ne iznenađuju, ali daju razlog za usmjeravanje stručne i znanstvene pozornosti s obzirom na potencijalne posljedice navedenih ponašanja. Relativno visoke frekvencije iskustva adolescenata s problemima u ponašanju kao što je konzumiranje alkohola i pušenje ne čude, s obzirom na to da je adolescencija razdoblje života u kojemu nisu neuobičajena različita eksperimentiranja, iskrivljena normativna uvjerenja i pozitivniji stavovi prema rizičnim ponašanjima (Cousijn, Luijten i Feldstein Ewing, 2019). Osim toga, konzumiranje alkohola jedno je od najraširenijih problema u ponašanju adolescenata globalno (WHO, 2018a; Europski centar za praćenje droga i ovisnosti o drogama, 2017). Velike razlike u procjeni među roditeljima i djecom pokazale su se i kod kockanja/klađenja, što pokazuje neznanje roditelja o uključenosti svoje djece u takve oblike ponašanja te govori u prilog autorima koji kockanje/klađenje nazivaju "skrivenom ovisnošću" (Barnes i sur., 1999). Naime, simptomi se kockanja jako teško uočavaju, a velik broj roditelja ne iskazuje veliku zabrinutost te procjenjuju kockanje manje rizičnim u odnosu na are evident, take place at home, and are not perceived as high-risk and adolescent engage in them openly. The lowest frequencies were observed in both adolescents and parents for the behaviors related to unprotected sex, teenage pregnancies and STDs (even though, in the latter case, significant parent-adolescent discrepancies were found). Relatively high frequencies were found for adolescent experience with alcohol consumption (57.9\%), smoking (44.5\%) and internalizing mental health problems, such as depressive episodes (35.3\%) and negative body image (39.8\%). On the other hand, only $11.2 \%$ of parents think that their children experienced depressive episodes. Very discrepant views were found for depressive episodes and addiction-related behaviors (alcohol consumption and gambling/betting).

These findings should not come as a surprise, but they should raise concern among experts and researchers given the potential negative effects. Relatively high frequencies for adolescent experience with behavioral problems such as alcohol consumption and smoking are nothing new since adolescence represents a life period characterized by experimentation, altered normative beliefs and positive perceptions of risk behaviors (Cousijn, Luijten and Feldstein Ewing, 2019). Furthermore, alcohol consumption remains one of the biggest problems in respect of adolescent behavior at a global level (WHO, 2018, European Monitoring Centre for Drugs and Drug Addiction, 2017). Significant parent-adolescent discrepancies were also found for gambling /betting, demonstrating that parents do not know that their children engage in these types of behavior and supporting the view of the authors who point to gambling/betting as a "hidden addiction" (Barnes et al., 1999). It is difficult to notice that someone is gambling. In addition, many parents do not seem particularly worried about it and perceive gambling as less risky than other 
druga rizična ponašanja (Campbell, Derevensky, Meerkamper i Cutajar, 2011). Maglica (2017) na uzorku hrvatskih roditelja iznosi rezultate da su roditelji osviješteni o raširenosti kockanja kao fenomenu i znaju da je to najraširenija igra na sreću među mladićima danas, ali imaju vrlo malo saznanja i svijesti koliko njihovi sinovi kockaju te koliko su razvili štetnih posljedica i problema vezanih uz kockanje. Ne iznenađuje ni rezultat da više od trećine mladih u uzorku navodi probleme u ponašanju koji se odnose na depresivnost i negativnu sliku o sebi, s obzirom da više od $20 \%$ mladih u dobi od 13 do 18 godina manifestira simptome anksioznosti i negdje od 10 do 15\% je depresivno (WHO, 2014, 2018). Rezultati hrvatske recentne studije provedene na uzorku od 10138 srednjoškolaca pokazuju da njih $32,5 \%$ iskazuje ozbiljne i vrlo ozbiljne simptome anksioznosti, a 21,3\% depresivnosti (Laboratorij za prevencijska istraživanja Edukacijsko-rehabilitacijskog fakulteta, 2020).

U odnosu na prvi istraživački problem, može se zaključiti da roditelji nemaju uvid u iskustva problema u ponašanju svoje djece. Naime, za gotovo sva ponašanja pokazala se razlika u procjenama na način da su adolescenti iskazivali veću uključenost $\mathrm{i}$ iskustvo s problemima u ponašanju, čime je potvrđena Hipoteza 1. Ti su rezultati u skladu s brojnim inozemnim istraživanjima koja su također potvrdila da roditelji imaju tendenciju podcjenjivati razinu uključenosti djece u rizična ponašanja i/ili rizike za uključivanje u takve oblike ponašanja (Berge i sur., 2015; Jones i sur., 2015). Objašnjenja za navedeno mogu biti brojna. Među ostalim, može biti riječ o roditeljskom nedostatku uvida, odnosno, neznanju koje proizlazi iz nezainteresiranosti i zanemarujućega odgojnog stila koji se u literaturi često navodi kao prediktor različitih problema u ponašanju (Baurmind, 1971; Strathearn i sur., 2021). Osim toga, roditeljsko neznanje o aktivnostima i ponašanjima može proizlaziti iz činjenice da je adolescencija risk behaviors (Campbell et al., 2011). Using a sample of parents in Croatia, Maglica (2017) has demonstrated that parents were aware of the prevalence of gambling and that they knew it was the most popular game of chance among young men at the time, yet, they did not know much about how frequently their sons engaged in gambling and how many gambling-related adverse effects and problems they had experienced. Furthermore, we should not be surprised by the fact that over a third of adolescent participants reported behavioral problems related to depressive episodes and negative body image because over $20 \%$ of young people aged 13-18 showed symptoms of anxiety and some 10-15\% experienced depression (WHO, 2014, 2018). Results of a recent Croatian study carried out on a sample of 10 138 secondary school students have shown that $32.5 \%$ reported serious and very serious anxiety symptoms and $21.3 \%$ experienced depressive episodes (Laboratory for Prevention Research (PrevLab), Faculty of Education and Rehabilitation Sciences, 2020).

In respect of the first research problem, one may conclude that parents do not have insights into their children's experience with behavioral problems. Discrepant views were found for all types of behavior whereby adolescents reported more experience with behavioral problems than their parents. This fact supports the Hypothesis 1. These findings go hand in hand with a bulk of foreign research that has confirmed how parents tend to underestimate the level of their children's engagement in risk behaviors and/or risk involvement (Berge, Sundell et al., 2015; Jones et al., 2015). Many factors may account for these findings. For example, parents may lack insights into their children's behavior or may be ignorant about it, as a result of lack of interest and neglectful parenting style that is (according to the literature) predictive of different behavioral 
razdoblje pojačane autonomnosti i neovisnosti od roditelja te nije rijetkost da djeca kriju različite informacije od roditelja (Kapetanovic i sur., 2020). Razlozi za to mogu biti u stjecanju osjećaja autonomnosti ili pak zaštite vlastite privatnosti (Rote i Smetana, 2016). U svakom slučaju, razlike u procjeni dobivene ovim istraživanjem govore u prilog zaključku da roditelji, općenito, nisu svjesni intenziteta uključenosti svoje djece u rizična ponašanja na način da ga podcjenjuju, što većina istraživanja prepoznaje kao snažan rizičan čimbenik, kao što je i opisano u samom uvodu rada. Velik raskorak između roditeljske percepcije i djetetova samoiskaza daje do znanja da je potrebno ulagati značajne napore $u$ informiranje i senzibilizaciju roditelja u tom području preventivnim i tretmanskim intervencijama.

Drugi istraživački problem odnosio se na utvrđivanje razlika u procjeni roditelja i adolescenata o učestalosti komunikacije o problemima u ponašanju. $U$ Tablici 2. prikazani su rezultati deskriptivne statistike, te je razvidno da roditelji u visokim postotcima procjenjuju čestu i redovitu komunikaciju, dok su postotci kod adolescenata puno niži. Primjerice, kada je u pitanju procjena komunikacije o konzumiranju alkohola, $62 \%$ roditelja procjenjuje da često i redovito komunicira sa svojom djecom o tome, dok svega $25 \%$ adolescenata navodi to isto. Slično je i pri procjeni učestalosti komunikacije o konzumiranju droga gdje je razvidno da $63,4 \%$ roditelja drži da često i redovito komunicira sa svojom djecom, dok adolescenti iskazuju svega $14,8 \%$.

Različiti postotci odgovora roditelja i adolescenata o procjeni učestalosti komuniciranja o problemima u ponašanju vidljivi su za sva ponašanja. Prema tim rezultatima treba se odnositi s posebnom pozornošću jer su istraživanja povezanosti rizičnih čimbenika u obitelji i npr. zlouporabe droga pokazala povezanost problems (Baurmind, 1971; Strathearn et al., 2021). Also, lack of parental knowledge about their children's behavior and activities may be due to the fact that adolescence is marked by increased autonomy and independence from their parents and children often hide information from parents (Kapetanovic et al., 2020). They might do that to gain a sense of autonomy or protect their privacy (Rote and Smetana, 2016). Either way, parent-adolescent discrepancies found in the research support the fact that, generally speaking, parents are not aware of the level of risk involvement of their children whereby they tend to underestimate it. Much research indicates that this is a strong risk factor, as explained in the introduction to this paper. Large discrepancies in parental perception and children's self-reports suggest that significant efforts have to be made to inform and raise parental awareness about these issues by implementing prevention and treatment intervention.

The second research problem was to establish discrepancies in parents' and adolescents' reports on parent-adolescent communication about behavioral problems. The Table 2 shows results of descriptive statistical analysis demonstrating that a large share of parents reported frequent and regular communication. In adolescents, this share is much lower in percentage terms. For instance, in terms of perceived communication about alcohol consumption, $62 \%$ of parents reported frequent and regular communication about this topic, compared with only $25 \%$ of adolescents. The same applies to frequency of communication about drug abuse whereby $63.4 \%$ of parents thought that they had frequent and regular communication with their children, as opposed to $14.8 \%$ of adolescents who shared their opinion.

Discrepancies in parents' and adolescents' reports on frequency of communication about 
Tablica 2. Odgovori roditelja $(n=445)$ i adolescenata $(n=447)$ o (samo)procjeni učestalosti komuniciranja o problemima u ponašanju.

Table 2. Parents' $(n=445)$ reports and adolescents' $(n=447)$ self-reports about frequency of communication about behavioral problems.

\begin{tabular}{|c|c|c|c|c|c|c|c|c|c|c|}
\hline \multirow[t]{2}{*}{$\begin{array}{l}\text { Problemi u ponašanju: } \\
\text { Behavioral problems: }\end{array}$} & \multicolumn{5}{|c|}{$\begin{array}{l}\text { Roditelji } \\
\text { Parents } \\
\text { (\%) }\end{array}$} & \multicolumn{5}{|c|}{$\begin{array}{l}\text { Adolescenti } \\
\text { Adolescents } \\
\text { (\%) }\end{array}$} \\
\hline & 1 & 2 & 3 & 4 & 5 & 1 & 2 & 3 & 4 & 5 \\
\hline $\begin{array}{l}\text { Vršnjačko nasilje u školi } \\
\text { School bullying }\end{array}$ & 1,6 & 10,6 & 38,9 & 34,4 & 14,6 & 28,2 & 35,3 & 28,0 & 7,2 & 1,3 \\
\hline $\begin{array}{l}\text { Konzumiranje alkohola } \\
\text { Alcohol consumption }\end{array}$ & 1,8 & 8,3 & 27,8 & 40,1 & 22,0 & 16,6 & 26,2 & 32,3 & 19,9 & 5,1 \\
\hline $\begin{array}{l}\text { Konzumiranje droga } \\
\text { Drug abuse }\end{array}$ & 2,9 & 7,2 & 26,5 & 36,0 & 27,4 & 32,5 & 29,6 & 23,1 & 10,3 & 4,5 \\
\hline $\begin{array}{l}\text { Nezaštićeni seksualni odnosi / maloljetničke trudnoće } \\
\text { Unprotected sex/teenage pregnancies }\end{array}$ & 6,5 & 25,3 & 34,3 & 22,6 & 11,2 & 43,0 & 26,0 & 17,4 & 8,7 & 4,9 \\
\hline $\begin{array}{l}\text { Pretilost / poremećaji hranjenja } \\
\text { Obesity/eating disorders }\end{array}$ & 10,1 & 26,1 & 34,2 & 19,3 & 10,3 & 39,1 & 27,3 & 18,8 & 8,7 & 6,0 \\
\hline $\begin{array}{l}\text { Kockanje/klađenje } \\
\text { Gambling/betting }\end{array}$ & 11,0 & 24,3 & 27,4 & 24,3 & 13,0 & 45,3 & 26,5 & 17,0 & 7,2 & 4,0 \\
\hline $\begin{array}{l}\text { Vožnja pod utjecajem alkohola } \\
\text { Driving under the influence (DUI) }\end{array}$ & 11,7 & 17,6 & 25,7 & 27,0 & 18,0 & 40,5 & 20,4 & 21,0 & 12,3 & 5,8 \\
\hline $\begin{array}{l}\text { Pušenje } \\
\text { Smoking }\end{array}$ & 4,9 & 12,4 & 27,4 & 34,8 & 20,4 & 16,8 & 21,1 & 22,9 & 25,3 & 13,9 \\
\hline $\begin{array}{l}\text { Provođenje previše vremena na internetu (Facebook, chat, } \\
\text { društvene mreže i dr.) } \\
\text { Spending too much time online (Facebook, chat, social } \\
\text { networks etc.) }\end{array}$ & 1,6 & 4,5 & 18,9 & 40,2 & 34,8 & 12,8 & 14,8 & 26,1 & 22,2 & 24,0 \\
\hline $\begin{array}{l}\text { Izloženost opasnostima i rizicima interneta } \\
\text { Exposure to cyber risks and threats }\end{array}$ & 3,6 & 6,9 & 22,6 & 27,3 & 27,3 & 27,4 & 24,3 & 21,8 & 15,7 & 10,8 \\
\hline $\begin{array}{l}\text { Depresivnost } \\
\text { Depressive episodes }\end{array}$ & 12,3 & 25,8 & 35,0 & 19,5 & 7,4 & 49,7 & 27,5 & 10,5 & 7,4 & 4,9 \\
\hline $\begin{array}{l}\text { Negativna slika o vlastitom tijelu } \\
\text { Negative body image }\end{array}$ & 12,1 & 27,5 & 34,2 & 17,9 & 8,3 & 48,9 & 20,6 & 17,3 & 7,4 & 5,8 \\
\hline $\begin{array}{l}\text { Pretjerano igranje videoigara } \\
\text { Heavy video gaming }\end{array}$ & 6,1 & 17,9 & 26,7 & 28,3 & 21,1 & 38,6 & 20,2 & 20,6 & 11,7 & 9,0 \\
\hline $\begin{array}{l}\text { Spolno prenosive bolesti } \\
\text { Sexually transmitted diseases (STDs) }\end{array}$ & 14,3 & 27,1 & 34,7 & 15,9 & 8,1 & 52,1 & 27,1 & 12,8 & 5,1 & 2,9 \\
\hline
\end{tabular}

Legenda/Legend: 1 = nikada/never, 2 = rijetko/rarely, $3=$ ponekad/sometimes, 4 = često/often, 5 = redovito/regularly

učestalosti konzumacije droga s roditeljskim stavovima, disciplini u obitelji, ali i učestalosti razgovora u obitelji o rizičnim ponašanjima (Ferić Šlehan i Kranželić, 2008). Osim konzumacije alkohola, Dixon i suradnici (2016) govore o povezanosti izostanka komunikacije na razini dijete - roditelj s problematičnim kockanjem djeteta. Posebno su zabrinjavajući podatci da, prema procjeni djece, $52,1 \%$ roditelja nikada ne govori o spolno prenosivim bolestima, $49,7 \%$ roditelja nikad ne govori o depresiji, $48,9 \%$ o negativnoj slici o sebi i $43 \%$ o nezaštićenim seksualnim odnosima i maloljetničkim trudnoćama. Opasnost tih rezultata leži u činjenici behavioral problems were found for all behaviors. Special attention should be paid to these results because research on connection between family risk factors and drug abuse (for instance) has found correlation between frequency of drug abuse on the one hand and parental attitudes and family discipline, but also frequency of family communication about risk behaviors, on the other hand (Ferić Šlehan and Kranželić, 2008). In addition to alcohol consumption, Dixon et al. (2016) point to the correlation between poor parent-child communication and problem gambling in children. It is alarming that, according to adolescent 
da je riječ o ponašanjima koja prema svojoj fenomenologiji svrstavamo u internalizirane probleme u ponašanju za koje je karakteristično da su manje vidljiva drugim ljudima te sklona podcjenjivanju (Novak i Bašić, 2008), a česta su $u$ adolescenciji, posebno kod djevojka.

Budući daje Shapiro-Wilkov test normalnosti pokazao odstupanje svih varijabli od normalne distribucije, koristilo se neparametrijskom statistikom. Stoga se za potrebe drugoga istraživačkog problema proveo Mann-Whitneyjev U-test kojim je utvrđeno da postoje razlike ( $p$ $<.001)$ u procjeni učestalosti komunikacije o problemima u ponašanju na način da roditelji procjenjuju svoju komunikaciju učestalijom nego što to procjenjuju adolescenti (Tablica 3.), čime se potvrdila Hipoteza 3.

Velik broj istraživanja govori u prilog dobivenim rezultatima. Naime, nije rijetkost da roditelji procjenjuju svoja ponašanja pozitivnijima nego što to procjenjuju njihova djeca (Hou i sur., 2019; Maglica, 2017; Ferić Šlehan i Kranželić, 2008). Takvi rezultati otvaraju brojna pitanja o kvaliteti komunikacije roditelja i djece te percepciji, doživljaju razgovora s djetetove i roditeljeve strane. Kao što je i ranije navedeno, takve razlike u percepciji u nekim su istraživanjima povezane s problemima u ponašanju kod adolescenata i njihovim slabijim mentalnim zdravljem (De Los Reyes i Kazdin, 2005; Guion i sur., 2009; Reynolds i sur., 2011). S druge strane, kvalitetna obiteljska komunikacija i činjenica da imaš bar jednog roditelja s kojim možeš podijeliti svoje probleme, utječe na osjećaj zadovoljstva vlastitim životom kod adolescenata (Levin, Dallago i Currie, 2012; Ackard, Neumark-Sztainer, Story, Perry i suradnici, 2006). Luk, Farhat, lannotti i Simons-Morton (2010) navode da kvalitetna i jednostavna komunikacija roditelja i njihovih sinova djeluje kao zaštitni čimbenik za konzumaciju marihuane i alkohola, a Cohen, Richardson i LaBree (1994) zaključuju da količina vremena reports, $52.1 \%$ of parents never talked to their children about STDs, $49.7 \%$ never talked about depression, $48.9 \%$ about negative body image and $43 \%$ about unprotected sex and teenage pregnancies. These results are disturbing because the listed behaviors represent internalizing behavioral problems, usually less visible to others and subject to underestimation (Novak and Bašić, 2008) and common in adolescence, especially in girls.

Nonparametric statistics was used since the Shapiro Wilk test for normality found deviations from a normal distribution for all variables. For that reason, for second research problem, the Mann-Whitney $U$ test was used. It found differences $(p<.001)$ in perceptions of communication about behavioral problems whereby parents overestimated the level of communication in terms of frequency compared with adolescents (Table 3 ) and this result has proved the Hypothesis 3.

Many studies support these results. Parents tend to perceive their behaviors in a more positive light than their children (Hou et al., 2019; Maglica, 2017; Ferić Šlehan, 2008). These results raise many questions about the quality of parent-child communication, as well as parents' and children's perception and views about communication. As previously stated, some research link these discrepancies to behavioral problems and poorer mental health among adolescents (DeReyes and Kazdin, 2005; Guion et al., 2009; Reynolds et al., 2011). On the other hand, adolescents feel more satisfied with their lives if they enjoy good family communication and have at least one parent to turn to (Levin, Dallago and Currie, 2012; Ackard, Neumark-Sztainer, Story, Perry et al. 2006). Luk et al. (2010) state that good and simple communication between parents and their sons acts as a protective factor against alcohol drinking and marijuana use. Cohen, 
Tablica 3. Razlike u (samo)procjeni učestalosti razgovora o problemima u ponašanju između roditelja $(n=244) i$ adolescenata $(n=244)$

Table 3. Discrepancies in parents' $(n=244)$ and adolescents' $(n=244)$ (self)reports on frequency of communication about behavioral problems

\begin{tabular}{|c|c|c|c|c|c|c|c|c|c|c|}
\hline \multirow{2}{*}{$\begin{array}{l}\text { Razgovor o: } \\
\text { Communication about: }\end{array}$} & \multicolumn{3}{|c|}{$\begin{array}{l}\text { Roditelji } \\
\text { Parents }\end{array}$} & \multicolumn{3}{|c|}{$\begin{array}{l}\text { Adolescenti } \\
\text { Adolescents }\end{array}$} & \multirow{2}{*}{ MW-U } & \multirow[b]{2}{*}{$\mathbf{z}$} & \multirow[b]{2}{*}{$\mathbf{p}$} & \multirow[b]{2}{*}{$\mathbf{r}$} \\
\hline & M & SD & $\begin{array}{l}\text { Mean } \\
\text { Rank }\end{array}$ & M & SD & $\begin{array}{l}\text { Mean } \\
\text { Rank }\end{array}$ & & & & \\
\hline $\begin{array}{l}\text { Vršnjačkom nasilju } \\
\text { School bullying }\end{array}$ & 2,84 & 1,15 & 591,33 & 2,18 & 97 & 302,32 & 35009,50 & $-17,297$ & $<.001$ & .78 \\
\hline $\begin{array}{l}\text { Konzumiranju alkohola } \\
\text { Alcohol consumption }\end{array}$ & 3,22 & 1,15 & 556,28 & 2,71 & 1,12 & 337,96 & 50942,00 & $-13,061$ & $<.001$ & .59 \\
\hline $\begin{array}{l}\text { Konzumiranju droga } \\
\text { Drug abuse }\end{array}$ & 3,01 & 1,32 & 591,83 & 2,25 & 1,15 & 300,50 & 34340,50 & $-17,275$ & $<.001$ & .78 \\
\hline $\begin{array}{l}\text { Nezaštićenim seks. odnosima / mlt. } \\
\text { trudnoćama } \\
\text { Unprotected sex/teenage pregnancies }\end{array}$ & 2,57 & 1,24 & 552,83 & 2,07 & 1,18 & 341,41 & 52481,50 & $-12,590$ & $<.001$ & .57 \\
\hline $\begin{array}{l}\text { Pretilosti / poremećajima hranjenja } \\
\text { Obesity/eating disorders }\end{array}$ & 2,54 & 1,23 & 531,37 & 2,15 & 1,21 & 362,01 & 61689,50 & $-10,102$ & $<.001$ & .46 \\
\hline $\begin{array}{l}\text { Kockanju/klađenju } \\
\text { Gambling/betting }\end{array}$ & 2,51 & 1,28 & 552,56 & 1,98 & 1,13 & 339,68 & 51815,00 & $-12,694$ & $<.001$ & .57 \\
\hline $\begin{array}{l}\text { Vožnji pod utjecajem alkohola } \\
\text { Driving under the influence (DUI) }\end{array}$ & 2,72 & 1,35 & 539,34 & 2,23 & 1,26 & 353,28 & 57789,00 & $-11,051$ & $<.001$ & .50 \\
\hline $\begin{array}{l}\text { Pušenju } \\
\text { Smoking }\end{array}$ & 3,26 & 1,23 & 499,19 & 2,98 & 1,30 & 392,93 & 75567,50 & $-6,336$ & $<.001$ & .29 \\
\hline $\begin{array}{l}\text { Provođenju previše vremena na internetu } \\
\text { Spending too much time online }\end{array}$ & 3,66 & 1,20 & 514,07 & 3,30 & 1,33 & 376,93 & 68497,50 & $-8,246$ & $<.001$ & .37 \\
\hline $\begin{array}{l}\text { Izloženosti opasnostima i rizicima interneta } \\
\text { Exposure to cyber risks and threats }\end{array}$ & 3,19 & 1,33 & 559,56 & 2,58 & 1,33 & 332,93 & 48918,50 & $-13,453$ & $<.001$ & .60 \\
\hline $\begin{array}{l}\text { Depresiji } \\
\text { Depressive episodes }\end{array}$ & 2,37 & 1,22 & 551,13 & 1,90 & 1,16 & 343,11 & 53241,00 & $-12,450$ & $<.001$ & .56 \\
\hline $\begin{array}{l}\text { Negativnoj slici o svom tijelu } \\
\text { Negative body image }\end{array}$ & 2,42 & 1,23 & 537,15 & 2,01 & 1,22 & 356,64 & 59382,50 & $-10,795$ & $<.001$ & .49 \\
\hline $\begin{array}{l}\text { Pretjeranu igranju videoigara } \\
\text { Heavy video gaming }\end{array}$ & 2,86 & 1,37 & 546,95 & 2,32 & 1,33 & 346,05 & 54658,00 & $-11,900$ & $<.001$ & .54 \\
\hline $\begin{array}{l}\text { Spolno prenosivim bolestima } \\
\text { Sexually transmitted diseases (STDs) }\end{array}$ & 2,28 & 1,19 & 555,35 & 1,80 & 1,04 & 339,65 & 51696,50 & $-12,957$ & $<.001$ & .59 \\
\hline
\end{tabular}

Legenda: $\mathrm{M}=$ aritmetička sredina; $\mathrm{SD}=$ standardna devijacija; Mean Rank = prosječni rang; $\mathrm{MW} U$ = Mann-Whitneyjev U-test; $p=$ značajnost razlike; $r$ = veličina efekta

Legend: $\mathrm{M}=$ mean; $\mathrm{SD}$ = standard deviation; Mean Rank; MW U = Mann-Whitney U-test; $p=$ significant difference; $r$ = effect size

koja se provodi u komunikaciji s djetetom i učestalost komunikacije roditelj - dijete utječe na smanjenje rizika konzumiranja alkohola i cigareta.

I u konačnici, treći istraživački problem bio je ispitati razloge koji obeshrabruju adolescente za razgovor s roditeljima o temama vezanim uz probleme u ponašanju, te postoji li razlika u procjeni tih razloga između roditelja i adolescenata. Rezultati deskriptivne analize (Tablica 4.) upozoravaju na to da adolescente u najvećoj mjeri obeshrabruje i sprečava od razgovora s
Richardson and LaBree (1994) conclude that the amount of time spent communicating with the child and frequency of parent-child communication decrease the risk for alcohol use and smoking.

Finally, the third research problem was to analyze the reasons that discourage adolescents from talking to their parents about topics related to behavioral problems and establish potential discrepancies in parents' and adolescents' perception of those reasons. The results of descriptive analysis (Table 4) demonstrate that 
Toni Maglica: Communication and Parental Knowledge about their Children's Experience with Behavioral...

\section{Tablica 4. Razlozi koji obeshrabruju (sprečavaju) adolescente od razgovora s roditeljima} ( $n=447$ adolescenata; $n=447$ roditelja)

Table 4. Reasons that discouraged (prevented) adolescents from talking to their parents ( $n=447$ adolescents; $n=447$ parents)

\begin{tabular}{|c|c|c|c|c|c|c|c|c|c|c|}
\hline \multirow[t]{2}{*}{$\begin{array}{l}\text { Razlozi: } \\
\text { Reasons: }\end{array}$} & \multicolumn{5}{|c|}{$\begin{array}{l}\text { Roditelji } \\
\text { Parents } \\
\text { (\%) }\end{array}$} & \multicolumn{5}{|c|}{$\begin{array}{l}\text { Adolescenti } \\
\text { Adolescents } \\
\text { (\%) }\end{array}$} \\
\hline & 1 & 2 & 3 & 4 & 5 & 1 & 2 & 3 & 4 & 5 \\
\hline $\begin{array}{l}\text { Strah od kažnjavanja } \\
\text { Fear of punishment }\end{array}$ & 46,4 & 18,7 & 17,8 & 14,0 & 3,2 & 50,3 & 15,3 & 21,8 & 8,8 & 3,8 \\
\hline $\begin{array}{l}\text { Strah od razočaranja } \\
\text { Fear of disappointment }\end{array}$ & 23,8 & 22,4 & 24,0 & 22,9 & 7,0 & 25,3 & 16,4 & 24,4 & 23,5 & 10,3 \\
\hline $\begin{array}{l}\text { Strah od reakcije roditelja } \\
\text { Fear of parental reaction }\end{array}$ & 18,8 & 20,1 & 25,8 & 27,6 & 7,7 & 15,5 & 15,5 & 25,5 & 28,0 & 15,7 \\
\hline $\begin{array}{l}\text { Misli/m da ga neće/u razumjeti } \\
\text { I/he/she think(s) that I/he/she will not } \\
\text { understand him/her }\end{array}$ & 21,9 & 19,0 & 23,8 & 29,0 & 6,3 & 24,0 & 20,9 & 20,9 & 21,3 & 12,9 \\
\hline $\begin{array}{l}\text { Misli/m da mi/mu ne mogu pomoći } \\
\text { I/he/she think(s) that I/he/she cannot help } \\
\text { him/her }\end{array}$ & 34,9 & 22,0 & 23,1 & 15,9 & 4,1 & 48,0 & 19,1 & 17,1 & 8,6 & 7,2 \\
\hline $\begin{array}{l}\text { Misli/m da Vi/roditelj ne znate/zna } \\
\text { dovoljno o tim temama } \\
\text { I/he/she think(s) that you/parent do(es) } \\
\text { not have sufficient knowledge about these } \\
\text { topics }\end{array}$ & 32,7 & 21,4 & 27,8 & 15,3 & 2,7 & 42,8 & 20,9 & 21,3 & 49,4 & 5,6 \\
\hline
\end{tabular}

Legenda: 1 = uopće se ne slažem da je to razlog; 2 = u velikoj mjeri se ne slažem; 3 = niti se slažem, niti se ne slažem; 4 = u velikoj mjeri se slažem i $5=$ u potpunosti se slažem da je to razlog

Legend: 1 = I strongly disagree that this is the reason; $2=1$ mostly disagree; $3=$ neither agree nor disagree; $4=\mid$ mostly agree and $5=$ I strongly agree that this is the reason

roditeljima strah od roditeljske reakcije $(43,7 \%)$, mišljenje da ih roditelji neće razumjeti (34,2\%) i strah od razočaranja (33,8\%). S druge strane, $u$ velikoj mjeri adolescente ne obeshrabruje i ne sprečava od razgovora s roditeljima mišljenje da im roditelj ne može pomoći $(67,1 \%)$ ili pak da roditelj ne zna dovoljno o tim ponašanjima (63,7\%). Također, velik postotak adolescenata $(65,5 \%)$ drži da razlog nije ni strah od kažnjavanja.

I kod roditelja su više frekvencije odgovora na razlozima koji se odnose na strah od reakcije roditelja $(35,3 \%)$ i da dijete misli da ga roditelj neće razumjeti (35,5\%). Zanimljivo je da i roditelji i adolescenti navode najviše postotke slaganja oko istih razloga koji obeshrabruju i sprečavaju djecu od razgovora s roditeljima.

Kod utvrđivanja razlika adolescenata i roditelja o razlozima koji obeshrabruju adolescente za razgovor, rezultati Mann-Whitneyjeva U-testa (Tablica 5.), pokazali su da postoje razlike u pro- adolescents indicated fear of parental reaction $(43.7 \%)$, conviction that parents would not understand them (34.2\%) and fear of disappointment as reasons why they felt discouraged and did not communicate with their parents. On the other hand, the conviction that the parent cannot help them (67.1\%) or that he/she did not have sufficient knowledge about the listed behaviors (63.7\%) did not seem to discourage and prevent them from talking to their parents to a significant degree. Furthermore, significant share of adolescents (65.5\%) did not attribute this to the fear of punishment.

In respect of parents, higher shares also indicated fear of parental reaction (35.3\%) and conviction that the child thought that the parent would not understand him/her (35.5\%). It is interesting to note that both parents and adolescents mostly agreed about the same reasons that discouraged and prevented adolescents from talking to their parents. 
Tablica 5. Razlike u procjeni razloga koji obeshrabruju (sprečavaju) dijete za komunikaciju s roditeljima među roditeljima $(n=244)$ i djecom $(n=244)$ (Mann-Whitneyjev U-test)

Table 5. Discrepancies in parents' $(n=244)$ and adolescents' $(n=244)$ reports on reasons discouraging adolescents from talking to their parents (Mann-Whitney U-test)

\begin{tabular}{|c|c|c|c|c|c|c|c|c|c|c|}
\hline \multirow{2}{*}{$\begin{array}{l}\text { Razlozi: } \\
\text { Reasons: }\end{array}$} & \multicolumn{3}{|c|}{$\begin{array}{l}\text { Roditelji } \\
\text { Parents }\end{array}$} & \multicolumn{3}{|c|}{$\begin{array}{l}\text { Djeca } \\
\text { Children }\end{array}$} & \multirow{2}{*}{ MW-U } & \multirow[b]{2}{*}{ z } & \multirow[b]{2}{*}{$\mathbf{p}$} & \multirow[b]{2}{*}{$\mathbf{r}$} \\
\hline & M & SD & $\begin{array}{l}\text { Mean } \\
\text { Rank }\end{array}$ & M & SD & $\begin{array}{l}\text { Mean } \\
\text { Rank }\end{array}$ & & & & \\
\hline $\begin{array}{l}\text { Strah od kažnjavanja } \\
\text { Fear of punishment }\end{array}$ & 2,09 & 1,21 & 454,08 & 2 & 1,2 & 435,94 & 94756,50 & $-1,128$ & $>.050$ & \\
\hline $\begin{array}{l}\text { Strah od razočaranja } \\
\text { Fear of disappointment }\end{array}$ & 2,67 & 1,26 & 435,16 & 2,77 & 1,33 & 453,76 & 94436,50 & $-1,108$ & $>.050$ & \\
\hline $\begin{array}{l}\text { Strah od reakcije roditelja } \\
\text { Fear of parental reaction }\end{array}$ & 2,85 & 1,23 & 414,56 & 3,13 & 1,29 & 468,56 & 85334,00 & $-3,230$ & $<.001$ & .14 \\
\hline $\begin{array}{l}\text { Misli da ga neće/(u) razumjeti } \\
\text { He/she think(s) that I/he/she will not } \\
\text { understand him/her }\end{array}$ & 2,79 & 1,25 & 443,71 & 2,78 & 1,36 & 440,29 & 96707,00 & $-0,204$ & $>.050$ & \\
\hline $\begin{array}{l}\text { Misli da mu ne mogu pomoći } \\
\mathrm{He} / \text { she think(s) that he/she cannot help me }\end{array}$ & 2,32 & 1,21 & 471,95 & 2,08 & 1,28 & 414,24 & 85133,50 & $-3,521$ & $<.001$ & .15 \\
\hline $\begin{array}{l}\text { Misli da Vi ne znate dovoljno o tim temama } \\
\text { He/she think(s) that you do not have } \\
\text { sufficient knowledge about these topics }\end{array}$ & 2,34 & 1,16 & 469,37 & 2,14 & 1,23 & 420,37 & 87991,50 & $-2,941$ & $<.010$ & .13 \\
\hline
\end{tabular}

Legenda: $\mathrm{M}=$ aritmetička sredina; $\mathrm{SD}=$ standardna devijacija; Mean Rank = prosječni rang; $\mathrm{MW} U \mathrm{U}=\mathrm{Mann}$-Whitneyjev $\mathrm{U}$-test; $\mathrm{p}=$ značajnost razlike; $r$ = veličina efekta

Legend: $M=$ mean; $S D=$ standard deviation; Mean Rank; MW U=Mann-Whitney U-test; $p=$ significant difference $r=$ effect size

cjeni razloga koji se odnosi na strah od reakcije roditelja $(\mathrm{p}<.001)$ na način da adolescenti u većoj mjeri procjenjuju taj razlog. Osim toga, razlika se pokazala u procjeni razloga koji se odnose na mišljenja da roditelj ne može pomoći $(p<.001)$ i mišljenja da roditelj ne zna dovoljno o rizičnim ponašanjima $(p<.010)$ na način da su te razloge više navodili roditelji, čime se potvrdila Hipoteza 3 ovog istraživanja.

Yau, Tasopoulos-Chan i Smetana (2009) navode da je upravo komunikacija o problemima u ponašanju od iznimne važnosti u doba adolescencije s obzirom da je riječ o ponašanjima koje roditelji žele prevenirati. Istraživanja usmjerena razlozima koji obeshrabruju adolescente od komunikacije s roditeljima govore u prilog našim nalazima, potvrđujući da je jedan od najučestalijih razloga strah od roditeljske reakcije (Smetana, Metzger, Gettman i Campione-Barr, 2006; Smetana, Villalobos, Tasopoulos-Chan, Gettman i Campione-Barr, 2009). Slično su dobili i Klineberg, Kelly, Stansfeld i Bhui (2013) u kvalitativnom istraživanju, u kojem sudionici navode strah od negativnih reakcija roditelja
When analyzing discrepancies in parents' and adolescents' reports on the reasons discouraging adolescents from talking to their parents, the results of the Mann-Whitney $U$ test (Table 5) point to discrepant views in terms of fear of parental reaction $(p<.001)$ whereby adolescents reported it more frequently than their parents. Also, discrepancies were found for conviction that the parent cannot help the child $(p<.001)$, as well as for the conviction that the parent did not have sufficient knowledge about risk behaviors $(p<.010)$ whereby parents listed these reasons to a higher degree. This has proved the Hypothesis 3 .

Yau, Tasopoulos-Chan and Smetana (2009) emphasize the importance of communication about behavioral problems in adolescence because parents want to prevent these types of behaviors. Research on reasons discouraging adolescents from talking to their parents support our findings and confirm that the fear of parental reaction represents one of the most common reasons (Smetana, 2006, 2009). In their qualitative research, Klineberg, Kelly, Stansfeld 
i okoline kada su u pitanju njihovi problemi u ponašanju. Brown, Bakken, Nguyen i Von Bank (2007) dobili su da je jedan od razloga i strah od kažnjavanja, što je u našem istraživanju procijenjeno u vrlo malim frekvencijama i kod adolescenata i kod roditelja.

\section{Ograničenja istraživanja i smjernice za buduća istraživanja}

Jedan od većih metodoloških izazova u kontekstu provedbe istraživanja bio je povezivanje roditelja i njihove djece adolescentne dobi. Budući da je jedan od osnovnih ciljeva istraživanja bio utvrđivanje razlika između roditelja i njihove djece, u radu su prikazani rezultati samo za onaj dio uzorka gdje se uspjelo povezati roditelje i djecu pa se dogodilo određeno osipanje uzorka. U odnosu na navedeno, očekivati je da se radi o pozitivnije selekcioniranoj skupini jer, primjerice, moguće je da adolescenti, koji su skloniji rizičnim ponašanjima, nisu bili na nastavi. $U z$ to, jedno od ograničenja leži u činjenici da se istraživanjem obuhvatio samo jedan roditelj (ili otac ili majka), tako da nedostaje perspektiva obaju roditelja koja bi, zasigurno, donijela sveobuhvatniju sliku obiteljske komunikacije. Osim navedenog, istraživanje je provedeno na prigodnom uzorku iako se vodilo računa da se proporcionalno obuhvate sve tri vrste srednjoškolskih obrazovnih programa.

Iz navedenog proizlaze i smjernice za buduća istraživanja. $U$ tom smislu bilo bi vrijedno provesti istraživanje na reprezentativnom uzorku te uključiti oba adolescentova roditelja. Također, bilo bi zanimljivo istražiti efekt spola roditelja i specifično ispitati očeve, a posebno majke, o komunikaciji, znanju o djetetu, nadzoru i dr. Na takav način dobio bi se sveobuhvatniji i kvalitetniji uvid u dinamiku obiteljskih odnosa i komunikacije. Osim efekta spola roditelja, bilo bi vrijedno istražiti i postoje li razlike u percepciji i samoprocjenama ispitivanih konstrukata $s$ and Bhui (2013) also found that, in terms of their behavioral problems, respondents indicated fear of negative reaction on the part of parents and people around them. Brown, Bakken, Nguyen and Von Bank (2007) also point to the fear of punishment. In our research, neither parents nor adolescents frequently reported on this.

\section{Research Limitations and Guidelines for Future Studies}

In respect of implementation of survey, one of the larger methodological challenges was to connect parents and their adolescent children. Given that one of the basic research goals was to identify discrepancies between parents and their children, the paper shows results for the part of the sample in which parents and children were connected so a certain amount of sample attrition occurred. That being said, one may expect that the sample included positively selected group, because at-risk adolescents may have skipped a class, for instance. In addition, the fact that one parent only (either father or mother) was included in the survey represents a limitation. In other words, the survey has not provided perspectives of both parents that would have generated more comprehensive overview of family communication. Furthermore, convenience sampling was used although all three types of secondary education were covered.

Guidelines for future studies arise from these remarks. In that sense, it would be very useful to implement this survey on a representative sample, covering both parents. Also, it would be interesting to analyze the effect of a parent's sex and examine separately fathers' and mothers' reports on communication, knowledge about their child, parental monitoring etc. This would allow for a more detailed and in-depth overview of dynamics of family relationships and communication. Apart from examining 
obzirom na spol djeteta. Uz to, bilo bi vrijedno provesti i longitudinalnu studiju kojom bi se na hrvatskom uzorku ispitali utjecaji dobivenih razlika na rizična ponašanja adolescenata, te kvalitetnije pridonijelo uzročno-posljedičnom zaključivanju o razvoju rizičnog ponašanja.

\section{ZAKLJUČAK}

Rezultati istraživanja prikazani u ovom radu govore u prilog postavljenim hipotezama te upućuju na to da roditelji podcjenjuju uključenost svoje djece i njihova iskustva s problemima u ponašanju. S druge strane, kad je u pitanju komunikacija o istim tim ponašanjima, roditelji percipiraju svoju komunikaciju puno češćom nego što to procjenjuju njihovi adolescenti. Dobiveni rezultati u skladu su s brojnim inozemnim istraživanjima te zavređuju posebnu pozornost jer se roditeljsko znanje o aktivnostima djece i kvalitetna komunikacija smatraju snažnim obiteljskim zaštitnim čimbenicima. Isto tako, utvrđene su razlike u procjeni roditelja i adolescenata kada su u pitanju razlozi koji obeshrabruju dijete za razgovor, a u najvećem postotku adolescenti kao razlog navode strah od reakcije roditelja. Navedeni rezultati mogu imati praktične implikacije na način da nude smjernice za preventivne intervencije. Naime, iz rezultata ovog istraživanja proizlazi da bi bilo značajno jačati roditeljske kompetencije, napose one koje se odnose na roditeljsko znanje i uključenost $u$ aktivnosti svoje djece, te one usmjerene kvalitetnoj komunikaciji, posebno kad su u pitanju teme vezane uz probleme $u$ ponašanju. the effect of a parent's sex, it would be useful to analyze discrepancies in perceptions and self-reports about the selected constructs by taking into account the child's sex. Finally, it would be helpful to conduct a longitudinal study on a Croatian sample analyzing the impact of discrepancies on adolescents' risk behaviors and thus make valuable contribution to drawing conclusions about risk behavior by relying on causal relationship.

\section{CONCLUSION}

Research results presented in the paper support the hypotheses and point to parents' underestimation of their children's engagement in behavioral problems and related experiences. Then again, in respect of communication about these types of behavior, parents tend to overestimate the level of communication compared with adolescents. These findings go hand in hand with numerous foreign research and call for attention because parental knowledge about their children's activities and high-quality communication are perceived as strong protective family factors. Also, we have found discrepancies in parents' and adolescents' reports on the reasons discouraging adolescents from talking to their parents, whereby adolescents mostly attributed this to the fear of parental reaction. These results may have practical implications by using them to create guidelines for preventive interventions. Research results demonstrate that it would be important to strengthen parental competences, in particular those related to parental knowledge and involvement in their children's activities, as well as high-quality communication, especially when it comes to topics connected to behavioral problems. 


\section{LITERATURA / REFERENCES}

Ackard, A. M., Neumark-Sztainer, D., Story, M. i Perry, C. (2006). Parent-child connectedness and behavioural and emotional health among adolescents. American Journal of Preventive Medicine, 30, 59-66.

Ajduković, M. i Kolesarić, I. (2003). Etički kodeks istraživanja s djecom. Zagreb: Državni zavod za zaštitu obitelji, materinstva i mladeži.

Barnes, G. M., Welte, J. W., Hoffman, J. H. i Dintcheff, B. A. (1999). Gambling and alcohol use among youth: influence of demographic, socialization and individual factors. Addictive Behaviors, 24(6), 749-767.

Baurmind, D. (1975). Current patterns of parental authority. Developmental Psychology, 4(1-2), 1-103.

Berge, J., Sundell, K., Öjehagen, A., Höglund, P. i Håkansson, A. C. (2015). Parental Awareness of Substance Use Among Adolescents in a Junior High School Sample. Journal of Drug Issues, 45(3), 263-278.

Bowlby, J. (1958). The nature of the child's ties to his mother. International Journal of Psychoanalysis, 39, 350-371.

Bowlby, J. (1969) Attachment and loss. Vol 1. Attachment. New York: Basic Books.

Bronfenbrenner, U. (1979). The Ecology of Human Development. Harvard University Press.

Brown, B. B., Bakken, J. P., Nguyen, J. i Von Bank (2007). Sharing information about peer relations: Parent and adolescent opinions and behaviors in Hmong and African American families. U B. Brown i N. Mounts (ur.), Linking parents and family to adolescent peer relations: Ethnic and cultural considerations (str. 67-82). San Francisco: Jossey-Bass.

Campbell, C., Derevensky, J., Meerkamper, E. i Cutajar, J. (2011). Parents perception of Adolescent Gambling: A Canadian National Study. Journal of Gambling Issues, 25, 36-53.

Campion, J., Javed, A., Vaishnav, M. i Marmot, M. (2020). Public mental health and associated opportunities. Indian Journal of Psychiatry. Preuzeto s: http://www.indianjpsychiatry.org (22.04.2021.).

Canale, N., Vieno, A., Bogt, T., Pastore, M., Siciliano, V. i Molinaro, S. (2016). Adolescent Gambling-Oriented Attitudes Mediate the Relationship Between Perceived Parental Knowledge and Adolescent Gambling: Implication for Prevention. Society for Prevention Research.

Cohen, D. A., Richardson, J. i Labree, L. (1994). Parenting behaviors and the onset of smoking and alcohol use: A Longitudinal Study. Paediatrics, 94, 368-375.

Cousijn, J., Luijten, M. i Feldstein Ewing, S. (2019). Adolescent Resilience to Addiction: a Social Plasticity Hypothesis. Lancet Child and Adolescent Health, 2, 69-78. https://dx.doi.org/10.1016/ S2352-4642(17)30148-7

Currie, C., Zanotti, C., Morgan, A., Currie, D., De Looze, M., Roberts, C. i Barnekow, V. (2012). Social determinants of health and wellbeing among young people. Health Behaviour in School-Aged Children (HBSC) Study: International Report from The 2009/2010survey.

De Kemp, A. T. R., Scholte, R. H. J., Overbeek, G. i Engels, R. C. M. E. (2006). Early Adolescent delinquency-the role of Parents and Best Friends. Criminal Justice and Behavior, 33(4), 488-510. https://doi.org/10.1177/0093854806286208.

De Los Reyes, A. L. i Kazdin, A. E. (2005). Informant discrepancies in the assessment of childhood psychopathology: A critical review, theoretical framework, and recommendations for further study. Psychological Bulletin, 131, 483-509. https://doi.org/10.1037/0033-2909.131.4.483. 
Dixon, R. W., Youssef, G. J., Hasking, P. i Yucel, M. (2016). The relationship between gambling attitudes, involvement, and problems in adolescence: Examining the moderating role of coping strategies and parenting styles. Addictive Behaviors, 58, 42-46.

Duell, N. i Steinberg, L. (2015). Positive risk taking in adolescence. Child Development Perspectives, 13(1), 48-52. https://doi.org/10.1111/cdep. 12310.

ESPAD Group (2020). ESPAD Report 2019- Results from the European School Survey Project on Alcohol and Other Drugs. Luxemburg: The EMCDDA Joint Publications, Publications Office of the European Union.

Europski centar za praćenje droga i ovisnosti o drogama (2017). Europsko izvješće o drogama 2017.: trendovi razvoj. Luxemburg: Ured za publikacije Europske unije.

Farrington, D. P., Loeber, R. i Ttofi, M. M. (2011). Risk and protective factors for offending. U B. C. Welsh i D. P. Farrington (ur.) The Oxford handbook of crime prevention. New York: Oxford University Press.

Ferić Šlehan, M. i Kranželić, V. (2008). Procjena rizičnih i zaštitnih čimbenika u zajednici: razlike između percepcije mladih i njihovih roditelja. Kriminologija i socijalna intergacija, 16(1), 33-43

Fletcher, A. C., Steinberg, L. i Williams-Wheeler, M. (2004). Parental influences on adolescent problem behavior: Revisiting Stattin and Kerr. Child Development, 75(3), 781-796. https://doi.org/ 10.1111/.1467-8624.2004.00706.x.

Gaylord, N. K., Kitzman, K. M. i Coleman, J. K. (2003). Parents' and children's perception of parental behavior: Associations with children's psychosocial adjustment in the classroom. Parenting: Science and Practice, 3(1), 23-47. https://doi.org/10.1207/S15327922PAR0301_02.

Glavak Tkalić, R., Miletić, G. M. i Maričić, J. (2016). Uporaba sredstava ovisnosti u hrvatskom društvu: Istraživanje na općoj populaciji. Zagreb: Institut društvenih znanosti Ivo Pilar.

Gohari, M. R., Cook, R. J., Dubin, J. A. i Leatherdale, S. T. (2020). Identifying patterns of alcohol use among secondary school students in Canada: A multilevel latent class analysis. Addictive Behaviors, 100. https://doi.org/10.1016/j.addbeh.2019.106120

Guion, K., Mrug, S. i Windle, M. (2009). Predictive value of informant discrepancies in reports of parenting: Relations to early adolescents' adjustment. Journal of Abnormal Child Psychology, 37, 17-30. https://doi.org/10.1007/s10802-008-9253-5.

Hamza, C. A. i Willoughby, T. (2011). Perceived parental monitoring, adolescent disclosure, and adolescent depressive symptoms: A longitudinal examination. Journal of Youth and Adolescence, 40, 902-915. https://doi.org/10.1007/s10964-010-9604-8.

Hawk, S. T., Hale, W. W., Raaijmakers, Q. A. W. i Meeus, W. (2008). Adolescents' perceptions of privacy invasion in reaction to parental solicitation and control. Journal of Early Adolescence, 28(4), 583-608. https://doi.org/10.1177/0272431608317611

Hessel, H., He, Y. i Dworkin, J. (2017). Paternal monitoring: the relationship between online and in-person solicitation and youth outcomes. Journal of Youth and Adolescence, 46, 288-299. https://doi.org/10.1007/s 10964-016-0490-6

Hou, Y., Benner, A.D., Kim, S.Y., Chen, S., Spitz, S., Shi, Y. i Beretvas, T. (2019). Discordance in parents' and adolescents' reports of parenting: A meta-analysis and qualitative review. American Psychologist, 75, 329-348. https://doi.org/10.1037/amp0000463

Jones, J. D., Ehrlich, K. B., Lejuez, C. W. i Cassidy, J. (2015). Parental knowledge of adolescent activities: Links with parental attachment style and adolescent risk behaviour. Journal of Family Psychology, 29, 191-200. https://doi.org/10.1037/fam0000070 
Kaltenegger, H. C., Låftman, S. B. i Wennberg, P. (2019). Impulsivity, risk gambling, and heavy episodic drinking among adolescents: A moderator analysis of psychological health. Addictive Behaviors Reports, 10. https://doi.org/10.1016/j.abrep.2019.100211

Kapetanovic, S. i Boson, K. (2020). Discrepancies in parents' and adolescents' reports on parent-adolescent communication and associations to adolescents' psychological health. Current Psychology: A Journal for Diverse Perspectives on Diverse Psychological Issues. Advance online publication. https://doi.org/10.1007/s 12144-020-00911-0

Kapetanovic, S., Bohlin, M., Skoog, T. i Gerdner, A. (2017). Structural relations between sources of parental knowledge, feelings of being overly controlled and risk behaviors in early adolescence. Journal of Family Studies, 26, 226-242. https://doi.org/10.1080/13229400.2017.1367713.

Kapetanovic, S., Rothenberg, W. A., Lansford, J. E., Bornstein, M. H., Chang, L., Deater-Deckard, K., Di Giunta, L., Dodge, K.A., Gurdal, S., Malone, P.S., Oburu, P., Pastorelli, C., Skinner, A.T., Sorbring, E., Steinberg, L., Tapanya, S., Uribe Tirado, L.M., Yotanyamaneewong, S., Alampay, L.P., Al-Hassan, S.M. i Bacchini, D. (2020). Cross-cultural examination of links between parent-adolescent communication and adolescent psychological problems in 12 cultural groups. Journal of Youth and Adolescence, 49, 1225-1244. https://doi.org/10.1007/s10964-020-01212-2

Keijsers, L., Branje, S. J. T., VanderValk, I. E. i Meeus, W. (2010). Reciprocal effects between parental solicitation, parental control, adolescent disclosure, and adolescent delinquency. Journal of Research on Adolescence, 20, 88-113. https://doi.org/10.1111/j.1532-7795.2009.00631.x.

Klineberg, E., Kelly, M. J., Stansfeld, S. A. et al. (2013). How do adolescents talk about self-harm: a qualitative study of disclosure in an ethnically diverse urban population in England? BMC Public Health, 13, 572. https://doi.org/10.1186/1471-2458-13-572

Koller-Trbović, N., Žižak, A. i Jeđud, I. (2011). Analiza postojećih definicija i prijedlog standarda za terminologiju, definiciju, kriterije i načine praćenja pojave poremećaja u ponašanju djece i mladih. (ekspertiza).

Laboratorij za prevencijska istraživanja (2020). Izvještaj „Kako je biti adolescent u Hrvatskoj danas? Preuzeto s: $h$ ttps://mzo.gov.hr/UserDocs/mages//dokumenti/ijesti/2019/2019//PRAG\%20-\%20 HR\%20MZO\%20sazetak\%20panelisti.pdf (16.10.2020).

Levin, K. A., Dallago, L. i Currie, C. (2012). The Association Between Adolescent Life Satisfaction, Family Structure, Family Affluence and Gender Differences in Parent- Child Communication. Social Indicators Research, 106(2), 287-305.

Luk, J. W., Farhat, T., lannotti, R. J. i Simons-Morton, B. G. (2010). Parent-child communication and substance use among adolescents: Do father and mother communication play a different role for sons and daughters? Addiction Behaviours, 35(5), 426-431.

Maglica, T. (2017). Obilježja roditeljstva i odnos roditelja prema kockanju kao prediktori kockanja muške djece (Doktorska disertacija). Edukacijsko-rehabilitacijski fakultet Sveučilišta u Zagrebu. Zagreb.

Maurizi, L. K., Gershoff, E. T. i Aber, J. L. (2012). Item-level discordance in parent and adolescent reports on parenting behaviour and its implications for adolescents' mental health and relationships with their parents. Journal of Youth and Adolescence, 41, 1035-1052. https://doi. org/10.1007/s10964-011-9741-8.

Meruelo, A. D., Castro, N., Cota, C. I. i Tapert, S. F. (2017). Cannabis and alcohol use, and the developing brain. Behavioral Brain Research, 325, 44-50. https://doi.org/ 10.1016/j.bbr.2017.02.025 
Mihić, J., Musić, T. i Bašić, J. (2013). Obiteljski rizični i zaštitni čimbenici kod mladih konzumenata i nekonzumenata sredstava ovisnosti. Kriminologija i socijalna integracija, 21(1), 49-62.

Novak, M. i Bašić, J. (2008). Internalizirani problemi kod djece i adolescenata: obilježja i mogućnosti prevencije. Ljetopis socijalnog rada, 15(3), 473-498.

Pinquart, M. (2017). Associations of parenting dimensions and styles with externalizing problems of children and adolescents: An updated meta-analysis. Developmental Psychology, 53, 873-932. https://doi.org/10.1037/dev0000295.

Polanczyk, G. V., Salum, G. A., Sugaya, L. S., Caye, A. i Rohde, L. A. (2015). Annual research review: a meta-analysis of the worldwide prevalence of mental disorders in children and adolescents. Journal of Child Psychology and Psychiatry, 56, 345-365.

Reynolds, E. K., MacPherson, L., Matusiewicz, A. K., Schreiber, W. M. i Lejuez, C. (2011). Discrepancy between mother and child reports parental knowledge and the relation to risk behavior engagement. Journal of Clinical Child and Adolescent Psychology, 40, 6779. https://doi.org/10.108 0/15374416.2011.533406

Ricijaš, N., Dodig Hundrić i D. Huić, A. (2016). Predictors of Adverse Gambling Related Consequences Among Adolescent Boys. Children and youth services review, 67, 168-174. https://doi.org/10.1016/j.childyouth.2016.06.008

Ricijaš, N., Dodig Hundrić, D. i Kranželić, V. (2015). Sportsko klađenje i druga rizična ponašanja hrvatskih srednjoškolaca. Hrvatska revija za rehabilitacijska istraživanja, 2, 41-56.

Rote, W. M. i Smetana, J. G. (2016). Beliefs about parents' right to know: Domain differences and associations with change in concealment. Journal of Research on Adolescence. https://doi. org/10.1111/jora.12194

Smetana, J. G., Metzger, A., Gettman, D. C. i Campione-Barr, N. (2006). Disclosure and secrecy in adolescent- parent relationships. Child Development, 77, 201-217.

Smetana, J. G., Villalobos, M., Tasopoulos-Chan, Gettman, D. C. i Campione-Barr, N. (2009). Early and middle adolescents' disclosure to parents about activities in different domains. Journal of Adolescence, 32, 693-713. https://doi.org/10.1016/j.adolescence.2008.06.010

Stattin, H. i Kerr, M. (2000). Parental monitoring: a reinterpretation: child development. Child Development, https://doi.org/10.1111/1467-8624.00210

Strathearn, L., Giannotti, M., Mills, R., Kisely, S., Najman, J. i Abajobir, A. (2021). Long-term Cognitive, Psychological, and Health Outcomes Associated with Child Abuse and Neglect. Paediatrics, 146(4), e20200438. https://doi.org/10.1542/peds.2020-0438

Tilton-Weaver, L., Kerr, M., Pakalniskeine, V., Tokic, A., Salihovic, S. i Stattin, H. (2010). Open up or close down: How do parental reactions affect youth information management? Journal of Adolescence, 33, 333-346. https://doi.org/10.1016/j.adolescence.2009.07.011.

Velez, C. E., Braver, S. L., Cookston, J. T., Fabricius, W. V. i Parke, R. D. (2020). Does Mattering to Parents Matter to Adolescent Mental Health? A Psychometric Analysis. Family Relations-Interdisciplinary Journal of Applied Family Science. https://doi.org/10.1111/fare. 12396

Wall, M., Cheslack-Postava, K, Hu, M., Feng, T., Griesler, P. i Kandel, D. B. (2018). Nonmedical prescription opioids and pathways of drug involvement in the US: Generational differences. Drug and Alcohol Dependence, 182, 103-111.

WHO (2014). Health for the World's adolescents: a second chance in the second decade, summary. Geneva, Switzerland: WHO. 
WHO (2018a). Adolescent alcohol-related behaviours: trend and inequalities in the WHO European Region, 2002-2014. Copenhagen: WHO, Regional Office for Europe.

WHO (2018b). Gender Disparities in Mental Health. https://www.who.int/mental_health/media/ en/242.pdf?ua $=1$

Yau, J. P., Tasopoulos-Chan, M. i Smetana, J. G. (2009). Disclosure to Parents about Everyday Activities among American Adolescents from Mexican, Chinese and European Backgrounds. Child Development, 8(5), 1481-1498. https://doi.org/10.1111/j.1467-8624.2009.01346.x

Ying, L., Ma, F., Huang, H., Guo, X., Chen, C., Xu, F. (2015). Parental monitoring, Parent-Adolescent Communication, and Adolescents' Trust in their Parents in China. PloS ONE, 10(8), e0134730. https://doi.org/10.1371/journal.pone.0134730 